\title{
Sarcomatoid Squamous Cell Carcinoma
}

\author{
Charmaine C. Anderson, Brian H. Le and Bernice Robinson-Bennett \\ The Reading Hospital and Medical Center \\ USA
}

\section{Introduction}

Although much has been characterized about squamous cell carcinoma of the lower female reproductive tract, there is limited knowledge and experience with cases demonstrating squamous cell carcinoma with sarcomatoid features. Sarcomatoid squamous cell carcinoma (SSCC) is mainly found in the upper aerodigestive tract with the larynx being the most common site in the head and neck region. (Otay et al., 2011) The esophagus and skin are other well known affected sites. In these sites, risk factors include, smoking, alcohol consumption, and previous irradiation of the head and neck region. (Otay et al., 2011) Risk factors for skin involvement include prolonged sun exposure and the effects of toxins and irradiation.

True sarcomas of the lower female genital tract arising in the vulva, vagina, and cervix, are extremely rare. They comprise only $1-2 \%$ of vulvar cancers, $2 \%$ of vaginal cancers (Temkin et.al,2007), $2-3 \%$ of cervical cancers, and $3 \%$ of endometrial cancers. They tend to be heterogeneous, rapidly progressive, with a high rate of recurrence and distant metastasis to organs such as liver and lungs. For the vulva and vagina, the main sites of occurrence are the labium majus and upper vagina, respectively. Leiomyosarcomas are the most common type of sarcoma in the female genital tract where several factors have been demonstrated to play a role in recurrence including tumor diameter, cytologic atypia, mitotic index, and infiltrating margins. Although there are no specific treatment guidelines, the mainstay of therapy has been surgical excision followed by chemotherapy. Neoadjuvant chemotherapy has been used in patients who have bulky tumors in which surgical debulking had not been optimal. Currently, some believe that neoadjuvant chemotherapy can also be used as primary therapy followed by surgical debulking regardless of tumor. It is thought that this treatment strategy can optimize surgical excision, giving rise to less morbidity, and a longer disease-free interval. (Temkin et.al,2007) The role of radiation therapy has been controversial as some believe that sarcomas themselves are induced by a history of radiation therapy or exposure. Nevertheless, there have been reports of radiation lengthening the time interval to local recurrence.

Sarcomatoid squamous cell carcinoma of the female genital tract has been reported in very small numbers. Human Papilloma Virus (HPV) has been known to be a major causal factor for the development of SCC. High risk subtypes of Human Papilloma Virus, 16 and 18, have been demonstrated in not only the squamous cell component of SSCC but also in the 
sarcomatoid component. Making immunohistochemical assays of this cancer a hallmark to diagnosis to differentiate pure squamous cell carcinoma from a pure sarcoma.

Like pure sarcomas, Sarcomatoid Squamous Cell Carcinoma has a very poor prognosis, short disease-free intervals, and is diagnosed at later stages of disease. Even with optimal treatment and follow up, SSCC recur rapidly and metastasize to regions such as the peritoneum, kidney, and subcutaneous tissue. Most cases of SSCC of the female genitalia have been reported to arise from the cervix and vulva. There are currently 16 cases of cervical and vulvar SSCC reported in the English literature to date. (Tae-Wook Kong et. al., 2010 and Dong-Seok Choi et. al., 2006), with our current case of vulvar SSCC making up the $17^{\text {th }}$ case.

SSCC of the Cervix Literature Review

\begin{tabular}{|c|c|c|c|c|c|c|c|}
\hline Author & $\begin{array}{l}\text { No. of } \\
\text { Cases }\end{array}$ & Age & FIGO & $\begin{array}{l}\text { Tumor } \\
\text { Diameter(cm) }\end{array}$ & $\begin{array}{l}\text { Primary } \\
\text { treatment }\end{array}$ & $\begin{array}{l}\text { Outcome } \\
\text { after } \\
\text { primary } \\
\text { treatment }\end{array}$ & $\begin{array}{l}\text { Survival } \\
\text { (months) }\end{array}$ \\
\hline $\begin{array}{l}\text { Steeper et al } \\
(1983)\end{array}$ & 1 & 67 & III & 10 & ERT & PD & 2, DOD \\
\hline Pang (1998) & 2 & $\begin{array}{l}65 \\
61\end{array}$ & $\begin{array}{l}\text { N/A } \\
\text { N/A }\end{array}$ & $\begin{array}{l}6 \\
5\end{array}$ & $\begin{array}{l}\text { RAH+CRT } \\
\text { RAH+CRT }\end{array}$ & $\begin{array}{l}\text { PD } \\
\text { RD }\end{array}$ & $\begin{array}{l}2, \text { DOD } \\
14, \text { DOD }\end{array}$ \\
\hline $\begin{array}{l}\text { Rodriques et } \\
\text { al }(2000)\end{array}$ & 1 & 39 & IB2 & 6 & $\mathrm{ERT}+\mathrm{RAH}$ & $\mathrm{RD}$ & $12, \mathrm{DOD}$ \\
\hline $\begin{array}{l}\text { Brown et al } \\
\text { (2003) }\end{array}$ & 9 & $\begin{array}{l}29 \\
32 \\
34 \\
39 \\
47 \\
57 \\
59 \\
59 \\
76 \\
\end{array}$ & $\begin{array}{l}\text { IB2 } \\
\text { IB2 } \\
\text { IB1 } \\
\text { IB } \\
\text { IIA } \\
\text { IVA } \\
\text { IVB } \\
\text { IVB } \\
\text { IIA } \\
\end{array}$ & $\begin{array}{l}4 \\
8 \\
1,6 \\
\text { N/A } \\
3 \\
\text { N/A } \\
\text { N/A } \\
\text { N/A } \\
5 \\
\end{array}$ & $\begin{array}{l}\text { RAH+ERT } \\
\text { ERT } \\
\text { RAH+CRT } \\
\text { ERT } \\
\text { ERT } \\
\text { ERT+exenteration } \\
\text { TAH+CTx } \\
\text { ERT } \\
\text { ERT }\end{array}$ & $\begin{array}{l}\text { RD } \\
\mathrm{CR} \\
\mathrm{CR} \\
\mathrm{RD} \\
\mathrm{CR} \\
\mathrm{RD} \\
\mathrm{RD} \\
\mathrm{RD} \\
\mathrm{CR}\end{array}$ & $\begin{array}{l}\text { N/A } \\
\text { 42, NED } \\
5, \text { NED } \\
\text { N/A } \\
40, \text { NED } \\
\text { N/A } \\
\text { N/A } \\
\text { N/A } \\
\text { 22, NED }\end{array}$ \\
\hline $\begin{array}{l}\text { Lin et al } \\
(2006)\end{array}$ & 1 & 31 & $\mathrm{~N} / \mathrm{A}$ & 6 & RAH & CR & 20, NED \\
\hline $\begin{array}{l}\text { Mohan et al } \\
(2008)\end{array}$ & 1 & 75 & IIB & 5,6 & ERT & CR & 10, NED \\
\hline $\begin{array}{l}\text { Kumar et al } \\
(2008)\end{array}$ & 1 & 54 & IIIB & 4 & CRT & CR & 6, NED \\
\hline $\begin{array}{l}\text { Tae-Wook } \\
\text { King et al } \\
\text { (2011) }\end{array}$ & 1 & 26 & IB1 & 2 & LRH & CR & 18, NED \\
\hline
\end{tabular}

Table 1. SSCC of the Cervix Reported Cases in the Literature (Tae-Wook King et al, 2010) $\mathrm{N} / \mathrm{A}=$ not available, $\mathrm{ER}=$ external pelvic radiation therapy, $\mathrm{RAH}=$ radical abdominal hysterectomy, $\mathrm{CRT}=$ chemoradiation therapy, $\mathrm{TAH}=$ total abdominal hysterectomy, $\mathrm{LRH}=$ laparoscopic radical hysterectomy, $\mathrm{PD}=$ progressive disease, $\mathrm{RD}=$ recurrent disease, $\mathrm{CR}=$ complete remission, $\mathrm{DOD}=$ dead of disease, $\mathrm{NED}=$ no evidence of disease 


\begin{tabular}{|c|c|c|c|c|c|c|c|c|c|c|}
\hline Authors & $\begin{array}{l}\mathbf{N} \\
\mathbf{0}\end{array}$ & Age & $\begin{array}{l}\text { FIGO } \\
\text { stage }\end{array}$ & $\begin{array}{c}\text { Histologic } \\
\text { report }\end{array}$ & $\begin{array}{l}\text { IF- } \\
\text { LN }\end{array}$ & $\begin{array}{c}\text { P- } \\
\text { LN }\end{array}$ & $\begin{array}{c}\text { Primary } \\
\text { treatment }\end{array}$ & $\begin{array}{c}\text { Adjuvant } \\
\text { therapy }\end{array}$ & DFI & Survival \\
\hline $\begin{array}{l}\text { Way } \\
(1960)\end{array}$ & 6 & - & - & $\begin{array}{c}\text { Epithelioma } \\
\text { of very } \\
\text { unusual type }\end{array}$ & NA & NA & $\begin{array}{l}\text { Surgical } \\
\text { treatment }\end{array}$ & - & NA & $\begin{array}{c}\text { No longer } \\
\text { than } 4.5 \\
\text { years }\end{array}$ \\
\hline $\begin{array}{c}\text { Gosling et } \\
\text { al (1961) }\end{array}$ & 2 & - & - & $\begin{array}{l}\text { Spindled } \\
\text { SCC }\end{array}$ & NA & NA & $\begin{array}{c}\text { Surgical } \\
\text { treatment }\end{array}$ & - & NA & NA \\
\hline $\begin{array}{l}\text { Copas et } \\
\text { al (1982) }\end{array}$ & 1 & 54 & III & $\begin{array}{c}\text { Poorly } \\
\text { differentiated } \\
\text { spindle cell } \\
\text { carcinoma }\end{array}$ & + & - & $\begin{array}{l}\text { RV with } \\
\text { bilateral } \\
\text { groin and } \\
\text { pelvic } \\
\text { LND }\end{array}$ & $\begin{array}{l}\text { CTx with } \\
\text { RTx }\end{array}$ & 1 month & $\begin{array}{c}2-3 \\
\text { months }\end{array}$ \\
\hline $\begin{array}{l}\text { Steeper et } \\
\text { al (1983) }\end{array}$ & 1 & 89 & - & $\begin{array}{l}\text { Pseudosarco } \\
\text { matous SCC }\end{array}$ & NA & NA & RTx & $\begin{array}{c}\text { Simple } \\
\text { vulvectomy }\end{array}$ & $\begin{array}{c}9 \\
\text { months }\end{array}$ & $\begin{array}{c}2.5 \\
\text { months }\end{array}$ \\
\hline $\begin{array}{l}\text { LiVolsi et } \\
\text { al (1987) }\end{array}$ & 2 & - & - & $\begin{array}{l}\text { Carcinoma } \\
\text { with } \\
\text { sarcomatoid } \\
\text { features }\end{array}$ & NA & NA & NA & NA & NA & NA \\
\hline $\begin{array}{l}\text { Santeusan } \\
\text { io et al } \\
(1991)\end{array}$ & 1 & 77 & IV & $\begin{array}{c}\text { Poorly } \\
\text { differentiated } \\
\text { carcinoma } \\
\text { with } \\
\text { sarcoma-like } \\
\text { features }\end{array}$ & + & NA & $\begin{array}{l}\text { RV with } \\
\text { bilateral } \\
\text { femoral } \\
\text { inguinal } \\
\text { LND }\end{array}$ & - & 15 days & 1 month \\
\hline $\begin{array}{l}\text { Parham et } \\
\text { al (1991) }\end{array}$ & 1 & 54 & I & $\begin{array}{c}\text { Mixed soft } \\
\text { tissue } \\
\text { sarcoma with } \\
\text { atypical } \\
\text { squamous } \\
\text { cells }\end{array}$ & NA & NA & $\begin{array}{l}\text { Local } \\
\text { excision }\end{array}$ & - & 3 years & $\begin{array}{c}\text { More than } \\
6 \text { years }\end{array}$ \\
\hline $\begin{array}{l}\text { Cooper et } \\
\text { al (2002) }\end{array}$ & 1 & 73 & III & $\begin{array}{l}\text { Sarcomatoid } \\
\text { SCC }\end{array}$ & + & NA & $\begin{array}{l}\text { RV with } \\
\text { bilateral } \\
\text { inguinal } \\
\text { LND }\end{array}$ & RTx & $\begin{array}{l}5 \mathrm{mo} \\
\text { nths }\end{array}$ & NA \\
\hline $\begin{array}{l}\text { Dong- } \\
\text { Seok et al } \\
(2006)\end{array}$ & 1 & 43 & II & $\begin{array}{c}\text { Poorly } \\
\text { differentiated } \\
\text { SCC with } \\
\text { extensive } \\
\text { sarcomatoid } \\
\text { features }\end{array}$ & - & NA & $\begin{array}{l}\text { Radical } \\
\text { local } \\
\text { excision } \\
\text { and } \\
\text { bilateral } \\
\text { groin } \\
\text { LND }\end{array}$ & NA & NED & $\begin{array}{c}\text { More than } \\
2 \text { years }\end{array}$ \\
\hline $\begin{array}{c}\text { Case } \\
\text { Number } \\
\text { Two } \\
\text { Below }\end{array}$ & 1 & 78 & I & $\begin{array}{c}\text { Poorly } \\
\text { differentiated } \\
\text { SSCC }\end{array}$ & - & - & $\begin{array}{l}\text { Bilateral } \\
\text { simple } \\
\text { hemivulv } \\
\text { ectomy }\end{array}$ & NA & NED & $\begin{array}{l}\text { Alive at } \\
\text { present } \\
\text { date }\end{array}$ \\
\hline
\end{tabular}

IF-LN = inguino-femoral lymph node metastasis, $\mathrm{P}-\mathrm{LN}=$ pelvic lymph node metastasis, $\mathrm{DFI}=$ disease free interval, $\mathrm{NA}=$ not available, $\mathrm{SCC}=$ squamous cell carcinoma, $\mathrm{NED}=$ no evidence of disease, $\mathrm{RV}=$ radical vulvectomy, $\mathrm{LND}=$ lymph node dissection, $\mathrm{CT} x=$ chemotherapy, $\mathrm{RT} x=$ radiation therapy

Table 2. SSCC of the Vulva Reported Cases in the Literature (D.-S. Choi et al, 2006)

Four cases of vaginal SSCC have been reported, with our current case constituting the fifth. 


\begin{tabular}{|c|c|c|c|c|c|c|}
\hline Authors & Age & Site & $\begin{array}{l}\text { FIGO } \\
\text { Stage }\end{array}$ & $\begin{array}{c}\text { Initial } \\
\text { Diagnosis }\end{array}$ & Treatment & Follow up \\
\hline $\begin{array}{c}\text { Steeper et } \\
\text { al (1983) }\end{array}$ & 54 & $\begin{array}{l}\text { Fornices } \\
\text { bilaterally } \\
\\
\text { Lower } \\
1 / 3 \\
\text { anterior, } \\
\text { extending } \\
\text { to labium } \\
\text { minus }\end{array}$ & $\begin{array}{l}\text { Positive } \\
\text { right } \\
\text { inguinal } \\
\text { nodes }\end{array}$ & $\begin{array}{c}\text { Malignant } \\
\text { fibrous } \\
\text { histiocytoma } \\
\text { Carcinosarcoma }\end{array}$ & $\begin{array}{l}8500 \text { rads with } \mathrm{F} / \mathrm{U} \\
\text { Adriamycin/vincristine } \\
\text { DTIC } \\
55 \mathrm{mg} \text { of intravaginal } \\
\text { radium, } 9990 \text { rad to } \\
\text { vaginal surface, and } \\
5075 \text { rad to right pelvic } \\
\text { lymph nodes }\end{array}$ & $\begin{array}{l}\text { Died } 11 \\
\text { months } \\
\text { after } \\
\text { diagnosis } \\
\text { Free of } \\
\text { recurrence } \\
4 \text { years } \\
\text { after } \\
\text { diagnosis }\end{array}$ \\
\hline $\begin{array}{l}\text { Motoyama } \\
\text { et al (1989) }\end{array}$ & 74 & $\begin{array}{l}\text { Middle } \\
1 / 3 \text { left } \\
\text { lateral }\end{array}$ & II & $\begin{array}{l}\text { Sarcomatous } \\
\text { spindle cell } \\
\text { tumor }\end{array}$ & $\begin{array}{l}7000 \text { rad external } \\
\text { radiation with } F / U \\
\text { vinicristine, } \\
\text { actinomycin } D, \\
\text { cyclophosphamide }\end{array}$ & $\begin{array}{c}\text { Died } 1 \\
\text { year after } \\
\text { diagnosis } \\
\text { with local } \\
\text { recurrence } \\
\text { and lung } \\
\text { metastasis }\end{array}$ \\
\hline $\begin{array}{l}\text { Raptis et } \\
\text { al (1993) }\end{array}$ & 25 & $\begin{array}{c}\text { Upper } \\
1 / 3 \text { left } \\
\text { lateral } \\
\text { wall }\end{array}$ & II & Sarcoma & $\begin{array}{c}4600 \mathrm{CGw} \text { external } \\
\text { radiation, and high } \\
\text { dose brachytherapy } 3 \mathrm{x} \\
800 \mathrm{cGw}\end{array}$ & $\begin{array}{c}\text { No } \\
\text { evidence } \\
\text { of disease } \\
6 \text { months } \\
\text { after } \\
\text { diagnosis }\end{array}$ \\
\hline $\begin{array}{c}\text { Case } \\
\text { number } 1 \\
\text { below }\end{array}$ & 67 & & III & Leiomyosarcoma & Radiation, Chemo & $\begin{array}{c}\text { Metastatic } \\
\text { disease at } \\
2 \text { years }\end{array}$ \\
\hline
\end{tabular}

Table 3. SSCC of the Vagina Reported Cases in the Literature (Raptis et al, 1993)

The low volume of cases poses a dilemma in that institutional encounters of such cases are sporadic and as such, there are no established guidelines for diagnosis or treatment. These cancers have traditionally been treated and staged similar to squamous cell carcinomas of their respective sites using the FIGO staging system. There has been reported success in long term survival rates of patients who present earlier in the disease and whose tumors could be fully resected. These presentations are rare, as patients tend to present with long standing bulky tumors and with metastasis.

\section{Case report}

Two cases of sarcomatoid squamous cell carcinoma, one of the vagina and one of the vulva, will be utilized as illustrative examples of this rare entity.

Case number one: 67 year old, Gravida 7 Para 6 woman status post total abdominal hysterectomy 13 years prior for reportedly benign fibroids, presented with profuse vaginal bleeding. Examination revealed a vaginal lesion which was biopsied, revealing a highgrade, malignant sarcomatoid neoplasm with no concurrent precursor lesion, such as an insitu component. Pathologic assessment suggested that this was a sarcoma, specifically, a leiomyosarcoma, as evidence of smooth muscle differentiation was demonstrated by immunohistochemisty. However, with subsequent demonstration of pelvic sidewall and pelvic lymph node involvement, features not typically associated with sarcomas, 
immunohistochemistry for p16 and in situ hybridization for high risk human Papilloma virus (HPV) subtypes was performed; this demonstrated that the tumor was, indeed, an HPV-driven malignancy compatible with sarcomatoid squamous cell carcinoma. Following a course of chemotherapy and radiation therapy, the patient presented two years later with deep vein thrombosis and obstructive uropathy, with subsequent biopsy demonstrating recurrent metastatic squamous cell carcinoma involving the ureter.
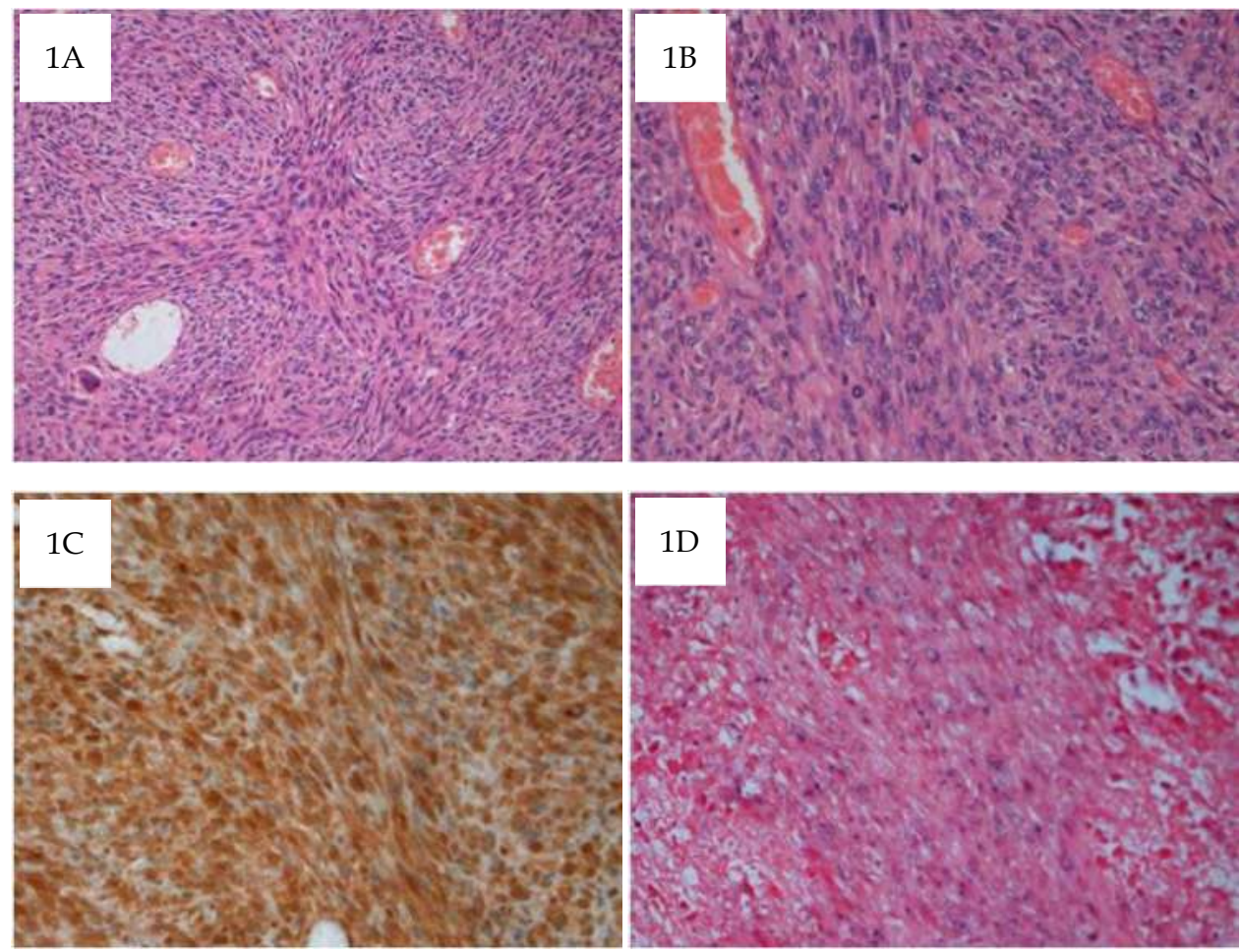

Fig. 1. Sarcomatoid squamous cell carcinoma of the vagina. (A) The lesion is characterized exclusively by spindled cells, architecturally arranged in fascicles. No in situ or conventional squamous cell morphology is apparent [200x original magnification]. (B) High-power magnification shows spindled cells with abundant mitotic figures [400x original magnification]. (C) Neoplastic cells show diffuse nuclear reactivity for $\mathrm{p} 16$, indicative of a HPV-driven tumor [400x original magnification]. (D) Chromogenic in situ hybridization for high-risk HPV subtypes demonstrates diffuse nuclear chromogenic labeling (in blue dot pattern) [400x original magnification].

Case number two: 78 year old Para 1 woman with long-standing vulvar irritation presented with a $4 \mathrm{~cm}$ vulvar lesion. She underwent biopsies that demonstrated a high-grade vulvar intraepithelial lesion (VIN III, carcinoma in situ), and subsequent wide local excision showed involved margins. Four years later, she re-presented with a $4 \mathrm{~cm}$, enlarging vulva mass; excision of this mass revealed an invasive, poorly differentiated Sarcomatoid Squamous Cell Carcinoma (SSCC), again with positive margins. She subsequently underwent a bilateral simple hemivulvectomy with pathology demonstrating involvement of the urethral margin, 
with other margins uninvolved. A metastatic evaluation was negative. Other comorbidities rendered the patient to be a poor candidate for additional surgical intervention.
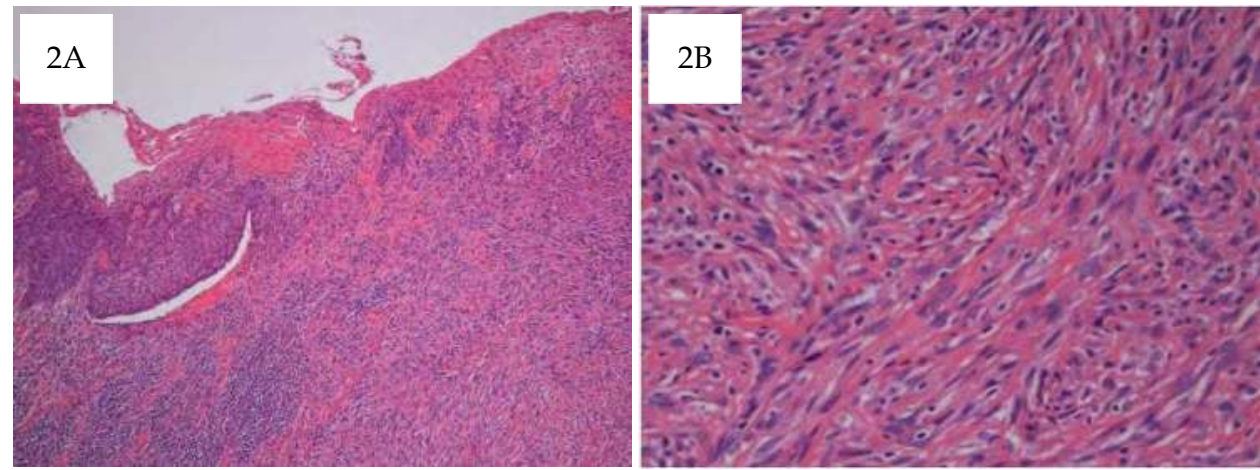

Fig. 2. (A) Sarcomatoid squamous cell carcinoma of the vulva. The lesion has an interface with an in situ component (left side of image), and transitions to a tumor of predominant spindled cell morphology (right side of image) [100x original magnification]. (B) Highpower magnification shows spindle cell morphology in a fascicular architectural pattern, imparting a mesenchymal-like, sarcomatoid morphology [400x original magnification].

\section{Incidence}

The incidences of SSCC has not been well established but is deemed to be very low from the isolated published case reports, constituting, at most only $1-2 \%$ of all gynecologic malignancies overall. There have been more reported cases of vulvar and cervical SSCC than cases from the vagina. This trend is also seen in squamous cell carcinomas of the female genital tract, with cervix and vulvar being more common than vagina. In general, SSCC are observed in more frequency with advancing age, and there is a correlation between vaginal cancers in women who have undergone a hysterectomy for malignant disease. It would be interesting to see if this is also true in SSCC. A possibility for the low incidence of SSCC is that the sarcomatoid component is under recognized, or under reported as part of the pathology report.

\section{Risk factors}

Risk factors for SSCC of the female genital tract are assumed to be the same as risk factors for Squamous cell carcinoma. This is even more so if the belief that SSCC transforms from SCC. Risk factors include HPV infection, high risk sexual behavior, cigarette smoking, specific vitamin deficiencies, and immunosupression.

Human Papillomavirus (HPV) is a well known causal factor for the development of squamous cell carcinoma of the vulva, vagina, cervix, anus, and oropharynx.It is the most frequently diagnosed sexually transmitted disease in the United States. HPV subtypes 16 and 18 in particular have a high known oncogenic potential and are thus called "high risk"subtypes, accounting for approximately $80 \%$ of cases of invasive cervical cancer. (Bereck and Hacker, 2010). HPV has been reported to affect roughly 20 million people in the U.S. and is the most frequently diagnosed STD. This number is expected to decrease as more 
young 2A 2B Sarcomatoid Squamous Cell Carcinoma 7 women and men are being offered the Gardasil and Cervarix injections. These injections are FDA improved and are aimed at immunizing against some of the "high risk" human papillomavirus types that predispose to cancer and the "low risk" subtypes of human papillomavirus that cause genital warts. Despite relatively wide availability, less than $30 \%$ of patients receive the recommended three doses. (NCI Cancer Bulletin, 2011) Even though the rates of HPV infection decrease sharply after 30 years of age, older women are less likely to clear an infection with a high risk subtype of HPV. The older the patient at presentation the more likely the patient will have a more advanced stage (Berek and Hacker 201

High risk sexual behavior is a risk factor due to the increase in exposure to sexually transmitted infections (STI). The more sexual partners one has the higher the chance that they will become infected with an STI. This is partly due to the fact that some STI's cause disruption of the epithelial cell layer that can facilitate the transport of infectious material. When the cervix is exposed to infection it undergoes reparative metaplastic changes that can also increase susceptibility of and STI. (Bereck and Hacker, 2010)

Cigarette smokers are known to be at increased risk of cancer of the lungs and other body organs including the cervix and vulva. Cigarette smoke is an independent risk factor for cervical cancer. (Nishino, K. et al, 2008) The pathogenesis is due to the elevated levels of genotoxic breakdown products that are in the cigarettes, including nicotine, cotinine, hydrocarbons, and tars, that have mutagenic properties that are present in cervical mucus and cells. (Berek and Hacker, 2010) Coker et al (2009) found that smokers were $21 \%$ more likely to succumb to cervical cancer compared to those who did not smoke at all, suggesting that it expedites the disease process due to the inhibited epithelial immune response.

Although there has been a lack of sound evidence that vitamins and minerals has a clinically significant affect on the progression and prevention of cancer (World Cancer Research Fund, 2007), there have been several studies that have shown a benefit of certain nutrients and vitamins. Research continues to find a correlation between essential vitamin and nutrient intake and the progression/prevention of breast, cervical, prostate, and colon cancer. Vitamins A, C, D, and E have been depicted to have protective properties. Vitamin A has some role in regulating differentiation, growth, and apoptosis of normal as well as malignant cells. (Cui et al, 2008) The role of Vitamin C has been in the foraging of free radicals. Vitamin $\mathrm{E}$ works in conjunction with vitamins $\mathrm{A}$ and $\mathrm{C}$ to regulate cell differentiation and proliferation, to scavenge free radicals and oxidants, and may reduce the persistence of HPV as well as inhibit cervical carcinogenesis by augmenting immunological function and modulating the inflammatory response to infection. (Kim et al, 2010) Toner and Milner (2010) found that even though Vitamin D has been shown to be beneficial in cancer prevention the problem lies in finding a standard and most beneficial dosage and also showed that there were risk with overexposure.

There are several disease states that can result in immunosupression. These include HIV, transplant patients, cancer patients undergoing chemotherapy, congenital immunodeficiency disorders, and immunosuppressive drugs, among others. The main physiological function of the immune cells is to monitor tissue homeostasis, to protect against invading pathogens, and to eliminate transformed or damaged cells. (Bremmes et al, 2011) When the physiologic function of immune cells are interrupted in any way, the body has an impeded response to the recognition and response to cancer cells. This delayed response and recognition aides in the 
more rapid progression of cancer. Studies on immunotherapy in cancer patients have been ongoing and there have been great advances, giving validity that the immune response is an important mediator in preventing and fighting off cancer.

\section{Pathogenesis}

There have been many hypotheses about the pathogenesis of SSCC, including the basis of its aggressiveness. The theory that is longstanding and the most accepted is that there is a transformation from the squamous cell carcinoma component into a spindle cell cancer. This is mainly due to parallel immunohistochemical, molecular, and ultrastructural characteristics. In 1960, Hay-Roe et al found that the epithelial portion of SSCC of the esophagus had an apparent tendency to become spindled in tissue culture. This was also reported by Sherwin et al (1963) which also stated there is a probable loss of unity of the epithelial cells in the basal layer and this was the major feature causing the spindle cell transformation. Raptis et. al (1993) showed a relative decrease in desmosomes and tonofilaments within the spindled component therefore lacking the structural foundation of ordinary squamous cell carcinoma and might be more susceptible to the compressing effect of surrounding stroma. The fact that the spindle cells have desmosomes and tonofilaments confirms the squamous cell origin. Lastly, there has been speculation that the spindle cell component and the squamous cell component arise concurrently from distinct stem cell lines and thus SSCC has been termed a "collision" tumor and not a single tumor with conversion to a spindled cell type. (Otay et al. 2011)

\section{Presentation}

The disease process of Sarcomatoid Squamous Cell Carcinoma is very aggressive, patients typically present with extensive local disease or with metastasis on imaging and during surgery. The clinical signs and symptoms do not correlate to the severity of disease. Early nonspecific symptoms can include fatigue, anemia, pelvic pain, pelvic pressure, constipation, bloating, weight loss, and loss of appetite.

The most common presenting symptom of cervical SSCC was abnormal vaginal bleeding. There have also been cases of patients complaining of a foul smelling discharge (Brown et al 2003), postcoital spotting (Kong et al, 2010). In all of the cases of cervical SSCC there was a visible cervical lesion ranging from $1.6 \mathrm{~cm}$ to $10 \mathrm{~cm}$. Vaginal lesions can present in a similar fashion with vaginal bleeding and a yellowish-white vaginal discharge. On physical exam a mass was usually palpable. Vulvar lesions usually present with the patient reporting a lesion that bleeds, is expanding, and/or is worrisome. In a small percentage of patients, there were no signs or symptoms of a genital mass. SSCC lesions of the cervix, vagina, and vulva, were all described similarly in the text as being ulceroproliferative, friable, of polypoid configuration, and necrotic in areas.

\section{Diagnosis}

The hallmark of diagnosing this disease is biopsy of the lesion. It is important to get an adequate specimen to increase the probability of accurately diagnosing the cancer. There is no consensus as to the diameter and depth of specimen that gives the highest yield for proper pathological evaluation. 
An excisional biopsy is one in which the entire mass is removed with a margin of normal tissue. This is done in the OR for the most part under sedation or if the lesion is small enough in the office with local anesthesia. Since the lesion is friable, supplies for bleeding should be readily available. Excisional biopsy is preferred for smaller lesions in which margins are available and do not interfere with surrounding structures. An incisional biopsy, in which the surgeon removes a portion of the mass, may be done in the office or in the operating room. This is utilitized in the event the mass is too large to obtain normal margin of surrounding tissue.

\subsection{Histology}

In general, the histopathological diagnosis of SSCC rests upon demonstration of a malignancy with regions of classic squamous cell carcinoma morphology, merging with those exhibiting a prominent spindle cell component. In cases where such a transition occurs, and/or where a squamous cell carcinoma in situ interface is evident, the diagnosis can be confidently rendered on morphologic grounds alone.

However, in situations where the spindled cell component predominates, without areas of classic squamous morphology or an interface with an in situ carcinoma component, the diagnosis is particularly challenging, as key differential diagnostic considerations would include a sarcoma. Such was the case with the current vaginal lesion, which was a tumor demonstrating exclusive spindled cell morphology; as immunohistochemistry for muscle markers (smooth muscle actin) was positive, the lesion was initially thought to reflect a leiomyosarcoma. In review of the cases, some report round to polygonal cells, scanty eosinophilic cytoplasm, irregular nuclei, prominent nucleoli, numerous mitosis, and areas of necrosis with interlacing bundles of spindle cells on microscopic exam.

\subsection{Immunohistochemical methodologies including HPV detection}

There are many tools in modern immunohistochemistry that may aid in facilitating the diagnosis of SSCC, but may also pose significant nuances. In our case of SSCC of the vagina, tumor cells which are exclusively spindled in morphology, were positive for markers associated with both, mesenchymal and epithelial differentiation, including cytokeratin, vimentin, desmin and smooth muscle actin. Indeed, while one report indicates that neoplastic cells of SSCC do not show reactivity for smooth muscle actin (C-P, Lin et al. 2006), another reports that this marker may be positive in tumor cells. (Brown et al., 2003). In our particular case of SSCC from the vagina, the tumor initially thought to reflect a leiomyosarcoma, was ultimately demonstrated to harbor high-risk HPV subtypes by in situ hybridization, as well as expression of p16, a tumor suppressor protein implicated in the HPV tumorigenesis pathway. These latter findings, despite the morphologic appearance of the tumor and the ambiguous immunophenotype, permitted a definitive final diagnosis of SSCC.

\section{Staging}

Due to the rarity of this cancer, the FIGO staging system that is used for squamous cell carcinoma is also used to stage SSCC of the vulva, vagina, and cervix. 


\begin{tabular}{|c|c|}
\hline Stage I & Tumor confined to the vulva \\
\hline - IA & $\begin{array}{l}\text { Lesions } \leq 2 \mathrm{~cm} \text { in size, confined to the vulva or perineum and with stromal } \\
\text { invasion } \leq 1.0 \mathrm{~mm}^{*} \text {, no nodal metastasis }\end{array}$ \\
\hline - $\quad$ IB & $\begin{array}{l}\text { Lesions }>2 \mathrm{~cm} \text { in size or with stromal invasion }>1.0 \mathrm{~mm}^{*} \text {, confined to the } \\
\text { vulva or perineum, with negative nodes }\end{array}$ \\
\hline Stage II & $\begin{array}{l}\text { Tumor of any size with extension to adjacent perineal structures }(1 / 3 \text { lower } \\
\text { urethra, } 1 / 3 \text { lower vagina, anus) }\end{array}$ \\
\hline Stage III & $\begin{array}{l}\text { Tumor of any size with or without extension to adjacent perineal structures } \\
\text { (1/3 lower urethra, } 1 / 3 \text { lower vagina, anus) with positive inguino-femoral } \\
\text { lymph nodes }\end{array}$ \\
\hline - $\quad$ IIIA & $\begin{array}{l}\text { i. With } 1 \text { lymph node metastasis }(\geq 5 \mathrm{~mm}) \text {, or } \\
\text { ii. } 1-2 \text { lymph node metastasis }(\mathrm{es})(<5 \mathrm{~mm})\end{array}$ \\
\hline - $\quad$ IIIB & $\begin{array}{l}\text { i. With } 2 \text { or more lymph node metastases }(\geq 5 \mathrm{~mm}) \text {, or } \\
\text { ii. } \quad 3 \text { or more lymph node metastases }(<5 \mathrm{~mm})\end{array}$ \\
\hline IIIC & With positive nodes with extracapsular spread \\
\hline Stage IV & $\begin{array}{l}\text { Tumor invades other regional ( } 2 / 3 \text { upper urethra, } 2 / 3 \text { upper vagina), or } \\
\text { distant structures }\end{array}$ \\
\hline - IVA & $\begin{array}{l}\text { Tumor invades any of the following: } \\
\text { i. upper urethral and/or vaginal mucosa, bladder mucosa, rectal mucosa, } \\
\text { or fixed to pelvic bone, or } \\
\text { ii. fixed or ulcerated inguino-femoral lymph nodes }\end{array}$ \\
\hline IVB & Any distant metastasis including pelvic lymph nodes \\
\hline
\end{tabular}

*The depth of invasion is defined as the measurement of the tumor from the epithelial-stromal junction of the adjacent most superficial dermal papilla to the deepest point of invasion. (FIGO Committee on Gynecologic Oncology. 2009)

Table 4. Carcinoma of the Vulva FIGO Staging. (2008)

\begin{tabular}{|l|l|}
\hline Stage I & The carcinoma is limited to the vaginal wall \\
\hline Stage II & $\begin{array}{l}\text { The carcinoma has involved the subvaginal tissue but has not extended to } \\
\text { the pelvic wall }\end{array}$ \\
\hline Stage III & The carcinoma has extended to the pelvic wall \\
\hline Stage IV & $\begin{array}{l}\text { The carcinoma has extended beyond the true pelvis or has involved the } \\
\text { mucosa of the bladder or rectum; bullous edema as such does not permit a } \\
\text { case to be allotted to stage IV }\end{array}$ \\
\hline - IVA & $\begin{array}{l}\text { Tumor invades bladder and/or rectal mucosa and/or direct extension } \\
\text { beyond the true pelvis }\end{array}$ \\
\hline - IVB & Spread to distant organs \\
\hline
\end{tabular}

(FIGO Annual Report. 2006)

Table 5. Carcinoma of the Vagina FIGO Nomenclature

Cervical cancer is still staged clinically, which is not always very accurate in portraying the extent of the disease. Clinical staging can include palpation, inspection, colposcopy, endocervical curettage, hysteroscopy, cystoscopy, proctoscopy, intravenous urography, and e-ray examination of the lungs and skeletal system. (Berek and Hacker, 2010) CT and MRI are also utilized often as this can give a better idea of extent of disease, margins, lymphadenopathy, and other organ involvement. Positron emission tomography (PET) is mainly utilized for nodal status. 


\begin{tabular}{|c|c|}
\hline Stage I & $\begin{array}{l}\text { The carcinoma is strictly confined to the cervix (extension to the corpus } \\
\text { would be disregarded) }\end{array}$ \\
\hline $\begin{array}{l}\text { IA } \\
\text { IA1 }\end{array}$ & $\begin{array}{l}\text { Invasive carcinoma which can be diagnosed only by microscopy, with } \\
\text { deepest invasion } \leq 5 \mathrm{~mm} \text { and largest extension } \leq 7 \mathrm{~mm} \\
\text { Measured stromal invasion of } \leq 3.0 \mathrm{~mm} \text { in depth and extension of } \leq 7.0 \mathrm{~mm} \\
\text { Measured stromal invasion of }>3.0 \mathrm{~mm} \text { and not }>5.0 \mathrm{~mm} \text { with an extension } \\
\text { of not }>7 \mathrm{~mm}\end{array}$ \\
\hline $\begin{array}{l}\text { IB } \\
\text { IB1 } \\
\text { IB2 }\end{array}$ & $\begin{array}{l}\text { Clinically visible lesions limited to the cervix uteri or pre-clinical cancers } \\
\text { greater than stage IA* } \\
\text { Clinically visible lesion } \leq 4.0 \mathrm{~cm} \text { in greatest dimension } \\
\text { Clinically visible lesion }>4.0 \mathrm{~cm} \text { in greatest dimension }\end{array}$ \\
\hline Stage II & $\begin{array}{l}\text { Cervical carcinoma invades beyond the uterus, but not to the pelvic wall or } \\
\text { to the lower third of the vagina }\end{array}$ \\
\hline $\begin{array}{ll} & \text { IIA } \\
\text { IIA1 } \\
\text { IIA2 }\end{array}$ & $\begin{array}{l}\text { Without parametrial invasion } \\
\text { Clinically visible lesion } \leq 4.0 \mathrm{~cm} \text { in greatest dimension } \\
\text { Clinically visible lesion }>4.0 \mathrm{~cm} \text { in greatest dimension }\end{array}$ \\
\hline - IIB & With obvious parametrial invasion \\
\hline Stage III & $\begin{array}{l}\text { The tumor extends to the pelvic wall and/or involves lower third of the vagina } \\
\text { and/or causes hydronephrosis or non-functioning kidney** }\end{array}$ \\
\hline - IIIA & $\begin{array}{l}\text { Tumor involves lower third of vagina, with no extension to the pelvic } \\
\text { sidewall }\end{array}$ \\
\hline - $\quad$ IIIB & Extension to the pelvic wall and/or hydronephrosis or non-functioning kidney \\
\hline Stage IV & $\begin{array}{l}\text { The carcinoma has extended beyond the true pelvis or has involved (biopsy } \\
\text { proven) the mucosa of the bladder or rectum. A bullous edema, as such, does } \\
\text { not permit a case to be allotted to Stage IV }\end{array}$ \\
\hline IVA & Spread of the growth to adjacent organs \\
\hline IVB & Spread to distant organs \\
\hline
\end{tabular}

*All macroscopically visible lesions-even with superficial invasion-are allotted to stage IB carcinomas. Invasion is limited to a measured stromal invasion with a maximal depth of $5.00 \mathrm{~mm}$ and a horizontal extension of not $>7.00$ $\mathrm{mm}$. Depth of invasion should not be $>5.00 \mathrm{~mm}$ taken from the base of the epithelium of the original tissue-squamous or glandular. The depth of invasion should always be reported in mm, even in those cases with "early (minimal) stromal invasion" ( 1 $\mathrm{mm}$ ). the involvement of vascular/lymphatic spaces should not change the stage allotment) ${ }^{*}$ On rectal examination, there is no cancer-free space between the tumor and the pelvic wall. All cases with hydronephrosis or non-functioning kidney are included, unless they are known to be due to another cause.

(FIGO Committee on Gynecologic Oncology. 2009)

Table 6. Carcinoma of the Cervix Uteri (2008)

\section{Therapy}

The rarity of these malignancies makes recommendations for standard treatments a formidable endeavor. In general, the stage of the cancer will dictate therapy.

In early stage disease of the vulva, vagina and cervix the role for surgery is more clearly defined. These lesions are usually treated with radical surgery followed by radiation therapy and/or chemotherapy in certain cases. Size, margin status, and local tumor biology might dictate the need for radiotherapy. Brown et al (2003) treated all Stage I and Stage II women with radiation therapy alone and this was successfully able to eradicate the tumor. This proves radiation to be an effective treatment option, even though some believe it to be a 
source of the transition of this cancer from SCC to the intermingling of the spindle shaped cells. In 2010, Kong et al reported a case of IB1 SSCC of the cervix in a young patient, being treated by laparoscopic radical hysterectomy, bilateral pelvic lymph node biopsy, peritoneal washing cytology and transposition of both ovaries without adjuvant therapy. Despite the initial treatment for low stage cancers, recurrent cancer did not respond to second line therapy (Brown et al, 2003) which leads some to take a more aggressive approach with surgery and adjuvant therapy, especially since time from recurrence to death is less than a year as reported in the literature.

In more advanced stages, patients present with such extensive disease that surgery is usually done on a palliative basis if indicated. These tumors are usually treated with concurrent chemotherapy and radiation, extrapolating from the pure squamous counterparts. In contradiction to these lesions where there exist more robust standard treatment recommendations the response to similar treatment is largely unknown and the risk for recurrence is very significant with a very short disease free interval.

\section{Prognosis}

Prognosis of SSCC is very poor. It is a very aggressive cancer, is usually diagnosed at a later stage, and most recur within one year despite aggressive combined therapy. As with the majority of solid tumors, the survival of patients that were detected at early stages is very reassuring. Patients who are diagnosed at Stage I have a higher survival rate at 5 years, approaching $90 \%$. In contrast, those who present at Stage IV, according to the studies, have a survival rate of less than $5 \%$ at five years, according to the review of the case reports. Prognostic factors have not been uniformed in any of the studies. Lane believed the extent of the grossly carcinomatous element was the best predictor of survival. Friedel et al found that not only was the degree of differentiation of the carcinomatous component an important prognostic factor but also the extent of invasiveness. Some suggest size and location are the sole factors impacting prognosis. (Randall et al.) Brown et al found that the younger patients tended to present at an earlier stage. Of these women who presented at stage 1, all were free of disease with the longest interval reported at 42 months. They also found that all patients less than 40 presented at Stage I and not a more advanced stage III or IV. One explanation for the fact that younger patients present at a lesser stage is that they are more prone to go to the doctors for acute visits and are more likely to voice there concerns over abnormal changes in their bodies. This is different to the belief that women $>40$ are more apt to cope with the symptoms and only present when the condition is debilitating or they are urged by family.

\section{Conclusion}

SSCC is a very rare cancer that has an aggressive and rapidly fatal course. Due to its rarity, there is no distinct staging or guidelines to direct therapy and care. As more cases become available and follow up is documented on patients with early FIGO stages, treatments, and surveillance decisions there will be a better chance of developing a set of guidelines based on the evidence. Since this cancer is most accepted as being a variant of SCC, the FIGO staging and treatment guidelines for squamous cell carcinoma are also used for SSCC.

Human papillomavirus has been implicated in SCC and is also found in the spindle cell component of SSCC. Even with the use of the widely available HPV vaccine and better 
screening modalities, it is difficult to discern which squamous cell cancers will transition to SSCC so no risk prevention can be done. One would assume that with the reduction in squamous cell carcinoma cases of the female genital tract that there will be a parallel reduction of SSCC.

Diagnosis has traditionally been difficult due to the large ratio of sarcomatous to squamous cell component. Immunohistochemistry and ancillary testing, such as in situ hybridization for high-risk HPV subtypes are very important for the precise diagnosis which can guide treatment and counseling of the patient. One should perform immunohistochemistry for squamous epithelial markers as well as in situ hybridization for HPV when encountering a sarcomatoid neoplasm to rule out SSCC.

As with any cancer, the lower the FIGO stage at diagnosis the better the prognosis. Unfortunately even when adequately treated according to unset standards, recurrence is very prevalent with disease free interval to death being very rapid. Once recurrence occurs there is very little recourse as the cancer does not respond to second line therapy and has usually extended out of the pelvis to distant organs. There have been few cases of a FIGO stage greater than II in which there has been long term survival but not enough to effectively alter the inevitable outcome.

\section{Acknowledgements}

The authors of this chapter have no financial acknowledgments.

\section{References}

Bereck, J.; Hacker, N. (2010) Gynecologic Oncology (5th), Lippincott, Williams, and Wilkins, ISBN 978-0-7817-9512-8, Philadelphia, Pennsylvania.

Bremnes, R.; Al-Shibli, K.; Donnem, T.; Sirera, R.; Al-Saad, S.; Anderson, S.; Stenvold, H.; Camps, C.; Busund, L. (2011) The Role of Tumor-Infiltrating Immune Cells And Chronic Inflammation at the Tumor Site on Cancer Development, Progression, and Prognosis: Emphasis on Non-small Cell Lung Cancer. Journal of Thoracic Oncology. Vol. 6, No. 4, (April 2011), pp. 824-33, ISSN 1556-0864

Brown, J.; Broaddus, R.; Koeller, M.; Burke,T.; Gershenson, D.; Bodurka, D. (2003). Sacrcomatoid Carcinoma of the Cervix. Gynecologic Oncology, Vol. 90, No. 1,(July 2003), pp. 23-28, ISSN 0090-8258

Choi, D.-S.; Lee, J.-W.; Lee, S.-J.; Choi, C.-H., Kim, T.-J.; Lee, J.-H.; Bae, D.-S.; Ahn, G.; Kim, B.G. (2006). Squamous Cell Carcinoma with Sarcomatoid Features of the Vulva: A case Report and Review of the Literature. Gynecologic Oncology, Vol. 103, No. 1, (October 2006), pp. 363-67, ISSN 0090-8258

Coker, AL; DeSimone, CP; Eggleston, KS; Hopenhayn, C; Nee, J; Tucker, T. (2009) Smoking And survival among Kentucky women diagnosed with invasive cervical Cancer: 1995-2005. Gynecologic Oncology, Vol. 112, No. 2, (February 2009), pp. 365-69, ISSN 1095-6859.

Cui, Y.; Shikany, JM.; Liu, S.; Shagufta, Y.; Rohan, TE. (2008) Selected antioxidants and risk Of hormone receptor-defined invasive breast cancers among post menopausal Women in the Women's Health Initiative Observational Study. American Journal of Clinical Nutrition. Vol. 87, No. 4, (April 2008), pp. 1009-18, ISSN 0002-9165

Hay-Roe, V.; Hill, R.; Civin, W. (1960) An Unclassified Tumor of the Esophagus: Case Review. Journal of Thoracic and Cardiovascular Surgery. Vol. 40, (July 1960), pp. 107-13, ISSN 0022-5223 
Iwata, H. (2008). Spindle Cell Squamous Cell Carcinoma Showing Epithelial Mesenchymal Transition. Journal of the European Academy of Dermatology and Venerology. Vol 23, No. 2, (February 2009), pp. 214-15, ISSN 1468-3083

Kim, J.; Kim, M.; Lee, J.; Kim, J-H.; Son, S.; Song, E-S.; Lee, K.; Lee, J.P.; Lee, J.M.; Yun, Y. Intakes of Vitamin A, C, E, and Beta-Carotene are Associated with Risk Of Cervical Cancer: A Case-Control Study in Korea. Nutrition and Cancer. Vol. 62, No. 2, (April 2009), pp. 181-89, ISSN 0163-5581.

Kong, T.-W.; Kim, J.-H.; Chang, S.-J.; Chang, K.-H.; Ryu, H.-S.; Joo, H.-J. (2010). Sarcomatoid Squamous Cell Carcinoma of the Uterine Cervix Successfully Treated by Laparoscopic radical Hysterectomy. Journal of Reproductive Medicine, Vol. 55, No. 8-9, (Sep-Oct 2010), 99. 445-48, ISSN 0024-7758

Kumar, M.; Bahl, A.; Sharma, D.; Agarwal, S.; Halanaik, D.; Kumar, R.; Raht, G. (2008) Sarcomatoid Squamous cell Carcinoma of Uterine Cervix: Pathology, imaging, and treatment. Journal of Cancer Research and Therapeutics, Vol. 4, No. 1, (Jan-Mar 2008), pp. 39-41, ISSN 0973-1482

Lin, C.-P.; Ho, C.-L.; Shen, M.-R.; Huang, L.-H.; Chou, C.-Y. (2006) Evidence of Human Papillomavirus Infection, Enhanced Phosphorylation of Retinoblastoma Protein, and Decreased Apoptosis in Sarcomatoid Squamous Cell Carcinoma Of Uterine Cervix. International Journal of Gynecologic Cancer, Vol. 16, No. 1, (Jan-Feb 2006), pp. 336-40, ISSN 1525-1438

Nishino, Koji.; Sekine, M.; Kodama, S.; Sudo, N.; Aoki, Y.; Seki, N.; Tanaka, K. (2008) Cigarette smoking and glutathione S-transferase M1 polymophism associated With risk for uterine cervical cancer. Japan Society of Obstetrics and Gynecology. Vol. 34, No. 6, (December 2008), pp. 994-1001, ISSN 1447-0756

Otay, M. (2011). Spindle Cell Carcinoma of the Tongue: A Rare Tumor in an Unusual Location. Pathology Research International. Vol. 2011, (01/2011), pp., ISSN 572381

Phillips, C. (2011) Use and Acceptance of HPV Vaccine Still a Work in Progress. NCI Cancer Bulletin, Vol. 8, No. 9, (March 2011), pp. 6, National Cancer Institute. Retrieved From http://www.cancer.gov/ncicancerbulletin/050311/page6

Raptis, S.; Haber, G.; Ferenczy, A. (1993). Vaginal Squamous Cell Carcinoma with Sarcomatoid Spindle Cell Features. Gynecologic Oncology, Vol. 49, No. 1, (April 1993), pp. 100-06, ISSN 0090-8288

Santeusanio, G.; Schiaroli, S.; Anemona, L.; Sesti, F.; Valli, E.; Piccione, E.; Spagnoli, L. (1991) Carcinoma of the Vulva with Sarcomatoid Features: A Case Report with Immunohistochemical Study. Gynecologic Oncology, Vol. 40. No. 2, (February 1991), pp. 160-63, ISSN 0090-8258

Sherwin, R.; Strong, M.; Vaughn, C. (1963). Polypoid and Junctional Squamous Cell Carcinoma of the Tongue and Larynx with Spindle Cell Carcinoma ("pseudocarcinoma"). Cancer, Vol. 16, (January 1963), pp. 51-60. ISSN 0008-543X

Steeper, T.; Piscioli, F.; Rosai, J. (1983). Squamous Cell Carcinoma with Sarcoma-Like Stroma of the Female Genital Tract: Clinicopathologic Study of Four Cases. Cancer. Vol. 52, No. 5, (September 1983), pp. 890-98, ISSN 0008-543X

Temkin, SM; Hellmann, M; Lee, Y; Abulafia, O. (2007) Primary Spindle Cell Sarcoma of the Vagina Treated with Neoadjuvant Radiation and Pelvic Exenteration. Journal of Lower Genital Tract Disease. Vol. 11, No. 2, pp. 105-07, ISSN 1089-2591

Toner, C.; Milner, J. (2010). The Vitamin D and Cancer Conundrum: aiming at a moving Target. Journal of the American Dietetic Association. Vol. 110, No. 10, (October 2010), pp. 1492-500, ISSN 0002-8223 


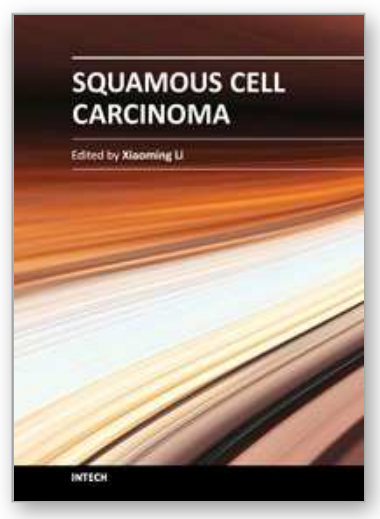

\author{
Squamous Cell Carcinoma
}

Edited by Prof. Xiaoming Li

ISBN 978-953-51-0024-9

Hard cover, 302 pages

Publisher InTech

Published online 03, February, 2012

Published in print edition February, 2012

This book points to some new areas for investigation on squamous cell carcinoma (SCC). Firstly, the features and management of some specific SCC is discussed to give the readers the general principles in dealing with these uncommon and sophisticated conditions. Some new concepts in adjuvant therapy including neoadjuvant therapy and gold nanoparticle-based photo dynamic therapy are introduced. Secondly, a detailed discussion of molecular aspects of tumor invasion and progression in SCC is provided with the emphasis on the roles of some important factors. The role of tumor microenvironment in head and neck SCC is specifically discussed. Thirdly, the roles of cancer stem cells (CSC) in cancer therapy of SCC are described. Molecular mechanisms involving therapeutic resistance and new therapeutic strategies targeting CSC are discussed in detail. Finally, other aspects concerning SCC are included, which involve the assessment, genetic manipulation and its possible clinical implications for the treatment of SCC.

\title{
How to reference
}

In order to correctly reference this scholarly work, feel free to copy and paste the following:

Charmaine C. Anderson, Brian H. Le and Bernice Robinson-Bennett (2012). Sarcomatoid Squamous Cell Carcinoma, Squamous Cell Carcinoma, Prof. Xiaoming Li (Ed.), ISBN: 978-953-51-0024-9, InTech, Available from: http://www.intechopen.com/books/squamous-cell-carcinoma/squamous-cell-carcinoma-withsarcomatoid-features-in-gynecologic-malignancies

\section{INTECH}

open science | open minds

\section{InTech Europe}

University Campus STeP Ri

Slavka Krautzeka 83/A

51000 Rijeka, Croatia

Phone: +385 (51) 770447

Fax: +385 (51) 686166

www.intechopen.com

\section{InTech China}

Unit 405, Office Block, Hotel Equatorial Shanghai

No.65, Yan An Road (West), Shanghai, 200040, China 中国上海市延安西路65号上海国际贵都大饭店办公楼 405 单元

Phone: +86-21-62489820

Fax: $+86-21-62489821$ 
(C) 2012 The Author(s). Licensee IntechOpen. This is an open access article distributed under the terms of the Creative Commons Attribution 3.0 License, which permits unrestricted use, distribution, and reproduction in any medium, provided the original work is properly cited. 